\title{
Current perspectives in stem cell research for knee cartilage repair
}

This article was published in the following Dove Press journal:

Stem Cells and Cloning:Advances and Applications

16 January 2014

Number of times this article has been viewed

\author{
Patrick Orth' \\ Ana Rey-Rico ${ }^{2}$ \\ Jagadeesh K Venkatesan ${ }^{2}$ \\ Henning Madry ${ }^{1,2}$ \\ Magali Cucchiarini² \\ 'Department of Orthopaedic \\ Surgery, ${ }^{2}$ Center of Experimental \\ Orthopaedics, Saarland University \\ Medical Center, Homburg, Germany
}

\begin{abstract}
Protocols based on the delivery of stem cells are currently applied in patients, showing encouraging results for the treatment of articular cartilage lesions (focal defects, osteoarthritis). Yet, restoration of a fully functional cartilage surface (native structural organization and mechanical functions) especially in the knee joint has not been reported to date, showing the need for improved designs of clinical trials. Various sources of progenitor cells are now available, originating from adult tissues but also from embryonic or reprogrammed tissues, most of which have already been evaluated for their chondrogenic potential in culture and for their reparative properties in vivo upon implantation in relevant animal models of cartilage lesions. Nevertheless, particular attention will be needed regarding their safe clinical use and their potential to form a cartilaginous repair tissue of proper quality and functionality in the patient. Possible improvements may reside in the use of biological supplements in accordance with regulations, while some challenges remain in establishing standardized, effective procedures in the clinics.
\end{abstract}

Keywords: cartilage repair, knee, focal defects, osteoarthritis, stem cells, clinical trials

\section{Introduction}

Articular cartilage lesions, especially those affecting the knee joint, as in acute trauma or osteoarthritis, remain a major unsolved clinical problem due to the poor intrinsic repair capacity of this highly specialized tissue. While various options are available for the clinician to repair a damaged joint surface, none can reliably restore the natural articular cartilage integrity, resulting in a limited ability of the tissue to withstand mechanical stresses during physical activities throughout life.

Strategies based on the application of stem cells that can be relatively easily acquired, expanded, and selectively committed towards a cartilaginous tissue may provide effective treatments for cartilage lesions in patients. Progenitor cells of potential value to achieve this goal and already applied using experimental models in vivo include bone marrow-derived mesenchymal stem cells (MSCs) and MSCs from the adipose tissue, synovium, periosteum, umbilical cord blood, muscle, and peripheral blood. The choice of the most suitable stem cell population for cartilage repair may depend on their availability and ease of preparation, and on their potential for chondrogenic differentiation. Active experimental work is also ongoing to identify an unlimited universal source of progenitor cells, such as embryonic stem cells and induced pluripotent stem cells, but many obstacles remain regarding their clinical use due to ethical considerations and safety issues (immune rejection, tumorigenesis, teratoma formation).
Correspondence: Magali Cucchiarin Center of Experimental Orthopaedics Saarland University Medical Center, Kirrbergerstr Bldg 37, D-6642I

Homburg, Germany Tel +49684 II 624987

Fax +49684 II 624988

Email mmcucchiarini@hotmail.com submit your manuscript $\mid$ www.dovepress.com

Dovepress

http://dx.doi.org/10.2147/SCCAA.S42880
Stem Cells and Cloning:Advances and Applications 2014:7 I-I7

(c) (i) (5) 2014 Orth et al. This work is published by Dove Medical Press Limited, and licensed under Creative Commons Attribution - Non Commercial (unported, v3.0) License. The full terms of the License are available at http://creativecommons.org/licenses/by-nd/3.0/. Non-commercial uses of the work are permitted without any further

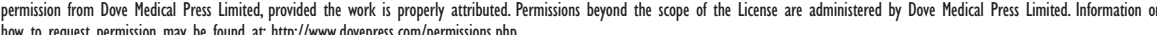
how to request permission may be found at: http://www.dovepress.com/permissions.php 
In this paper, we provide an overview of the stem cellbased treatments and surgical procedures employed in the clinic to promote and evaluate cartilage repair in focal defects and for osteoarthritis, with a depiction of biocompatible materials used for stem cell delivery in patients. We also describe innovative strategies based on possible biological supplementation of the approaches to improve healing of lesions in the future. Finally, we discuss some of the challenges for optimal clinical use of stem cells in patients in light of knowledge about natural cartilage repair and the results of reported clinical trials in terms of methodology, regulation, and quality of repair of lesions.

\section{Principles of articular cartilage repair \\ Structure and function of articular cartilage}

The major function of articular cartilage is to allow for smooth gliding of the articulating surfaces of a joint and to protect the subchondral bone from mechanical stress. Remarkably, adult hyaline articular cartilage is avascular, aneural, and does not have lymphatic drainage. ${ }^{1}$ It is structured in several laminar zones and formed by chondrocytes that are surrounded by an intricate network of extracellular matrix. ${ }^{2}$ Articular chondrocytes synthesize and degrade the extracellular matrix, thereby regulating its structural and functional properties according to the loads applied. This cartilaginous matrix is rich in proteoglycans and collagen fibrils composed of type II collagen, but also comprises type VI, IX, XI, and XIV collagen and a number of additional macromolecules, including cartilage oligomeric matrix protein, link protein, decorin, fibromodulin, fibronectin, and tenascin. ${ }^{3}$ Normal hyaline articular cartilage contains about $70 \%-80 \%$ water, which is mainly bound to proteoglycans. The basal region of the articular cartilage is characterized by increased mineral density. ${ }^{4}$ This layer of calcified cartilage is closely connected to the underlying subchondral bone. ${ }^{5}$

\section{Deterioration of articular cartilage}

Lesions of the cartilaginous joint surface may either be of limited extent in focal articular cartilage defects or generalized during osteoarthritis (Figure 1A). In focal defects, the structural integrity of the articular cartilage is disrupted in circumscribed areas, for example as a consequence of direct trauma, osteonecrosis, or osteochondritis dissecans. The resulting articular cartilage defect is of a limited two-dimensional extent and characterized as being either chondral, involving only the cartilaginous zones, or osteochondral, reaching further into the subchondral bone. ${ }^{5}$

Osteoarthritis instead, is a chronic, degenerative disorder of the diarthrodial joints, characterized mainly by an activation of inflammatory and catabolic cascades at the molecular level, ultimately leading to a gradual deterioration of the articular cartilage. ${ }^{6}$ Under mechanical or biochemical stress (local production of proinflammatory cytokines and mediators such as interleukin- $1 \beta$, tumor necrosis factor- $\alpha$, nitric oxide, prostaglandins, or matrix degradation products), the chondrocytes undergo pathological changes in their gene expression patterns that impair the cartilage homeostasis (diminished production of native matrix molecules versus enhanced production of matrix-degrading enzymes and decreased responsiveness to reparative stimuli), ultimately resulting in matrix degradation and cell senescence with apoptosis. ${ }^{6}$ Osteoarthritis may also be the result of a previous injury to tendons and ligaments or following intra-articular fractures, leading to joint instability and articular cartilage wear (secondary osteoarthritis). Of note, osteoarthritis affects not only the cartilage but also the subchondral bone, and (to a minor degree) the synovial lining, ligaments, tendons, and muscles.

\section{Spontaneous cartilage repair}

Repair and regeneration of articular cartilage are entirely different processes and need to be distinguished. Cartilage repair leads to a tissue that shares structural similarities with hyaline articular cartilage with regard to the macroscopic aspect or cell type. However, this repair tissue manifests neither an arcade-like organization of its fibers nor a well-defined zonal stratification of its chondrocytes. ${ }^{7}$ Its biochemical composition is more akin to fibrous than hyaline cartilage, ${ }^{8}$ and its mechanical competence is significantly inferior to that of the latter. ${ }^{9}$ Thus, native hyaline cartilage is not re-established in this repair process. ${ }^{10}$ In contrast, cartilage regeneration is defined as the restitution ad integrum of articular cartilage at the histological, biochemical, and biomechanical levels, making it indistinguishable from the adjacent uninjured cartilage. ${ }^{11}$ It is noteworthy that, in contrast with repair, regeneration of tissues readily occurs only in embryos, while it is almost absent in neonates and never noted in adults. ${ }^{11}$

Focal chondral and osteochondral defects exhibit fundamental differences in the history of natural repair. Due to a lack of vascularization in the articular cartilage, access of progenitor cells to the site of a chondral lesion is limited. Thus, chondral defects are in part repopulated by cells that are migrating from the synovial membrane. ${ }^{7,12}$ However, filling 
A
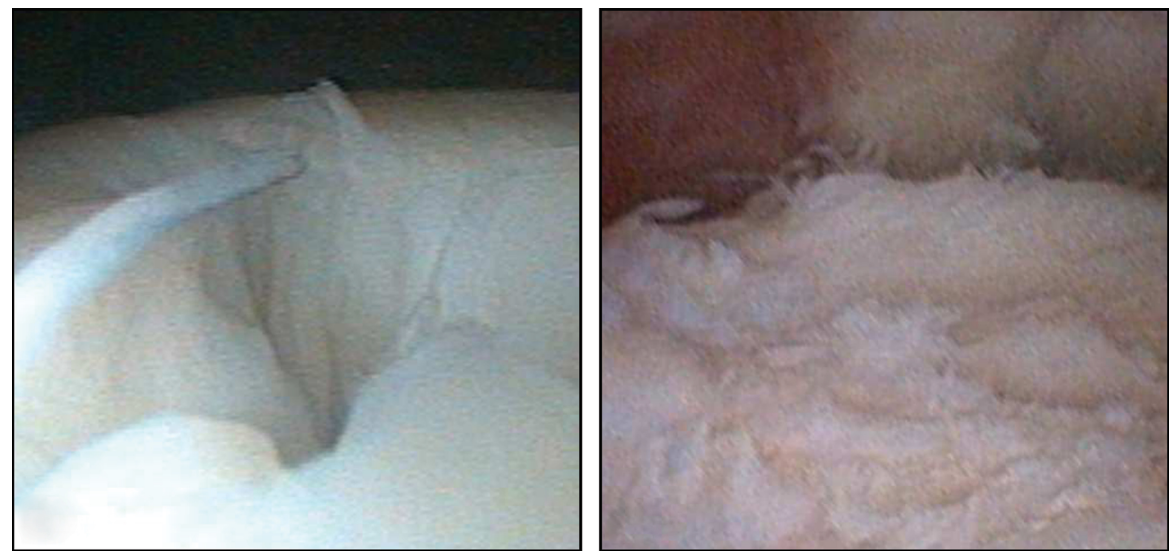

B

Stem cells

- Recombinant factor

- Gene transfer vector

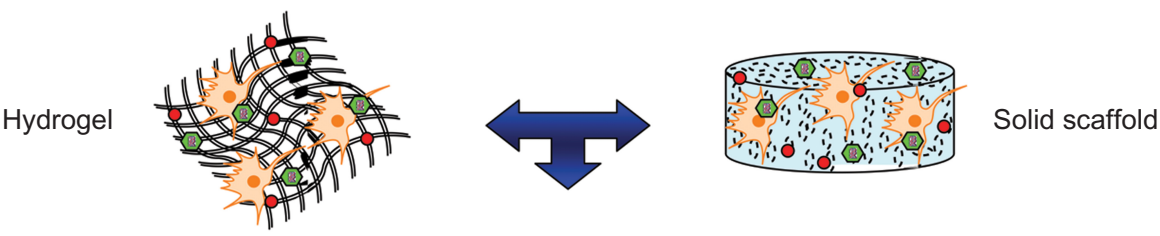

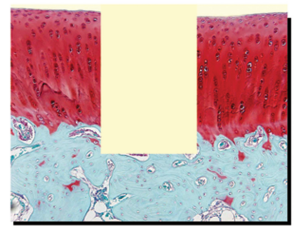

Cartilage defect

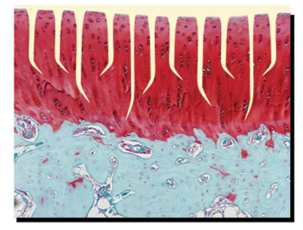

Osteoarthritic cartilage

Figure I (A) Articular cartilage lesions. (I) Focal cartilage defect in a 28-year-old man and (2) osteoarthritic cartilage in a 49-year-old woman. (B) Therapeutic components of potential value to deliver stem cells for cartilage repair.

such defects is insufficient, and after some weeks or months, the repair tissue inevitably begins to degenerate. Furthermore, it integrates poorly, causing focal discontinuity and regions of hypocellularity and cluster formation within the neighboring cartilage. ${ }^{13}$ Ultimately, these regions of the contiguous surface become necrotic, showing neither remodeling nor resorption. ${ }^{14}$ Over time, this may lead to an increase in the size of the defect.

In contrast, an osteochondral defect is filled with a blood clot that forms if the bone marrow communicates with the defect. ${ }^{13,14}$ Pluripotent mesenchymal cells present in the blood clot differentiate into chondrocytes and osteoblasts that later form the cartilaginous repair tissue and the reconstituted subchondral bone, respectively. The process of chondrogenesis is completed after some months and indicated by the appearance of round cells and the presence of a new cartilaginous matrix. Depending on the maturation of repair tissue, this cartilaginous matrix contains proteoglycans and type I and type II collagen in different ratios. ${ }^{14}$ Specifically, expression of type I collagen, type I-associated collagen types (V, VI, $\mathrm{XII}, \mathrm{XV}$ ), and proliferative cell markers is upregulated in the repair tissue compared with normal articular cartilage, while transcription abundance is higher in normal cartilage for proteoglycans, noncollagenous adhesion proteins, and for biomarkers of cartilage development. ${ }^{15}$ The repair tissue has an increased water content but decreased Young's and equilibrium modulus relative to the neighboring cartilage, ${ }^{16}$ exhibiting aggrecan and type II collagen content which 
gradually increases over time. ${ }^{17,18}$ However, this repair tissue does not integrate with the existing adjacent matrix; chondrocytes within the neighboring articular cartilage do not participate in the filling of the defect but undergo apoptosis over time, and the cartilage in this region becomes acellular. After some months, the new tissue within the defect exhibits a fibrocartilaginous phenotype and early signs of degeneration are visible. Both, the repair tissue and the cartilage at the periphery of the defect do not withstand mechanical load over time and degenerate after several years. ${ }^{13}$ If left untreated, the size of the defect extends into the surrounding normal cartilage, and generalized osteoarthritis of the joint may result.

In osteoarthritis, the repair capacity of articular cartilage is compromised. As the critical size of a cartilage defect to repair is $3 \mathrm{~cm}^{2}$, ${ }^{19}$ the larger lesions occurring in osteoarthritis do not allow for sufficient filling of the defect and containment of the repair tissue. ${ }^{7}$ Thus, osteoarthritic cartilage deterioration remains irreparable and progresses over time. Of note, mechanosensitive osteoblasts ${ }^{20}$ within the subchondral bone may be activated by altered biomechanical loading following cartilage deterioration in osteoarthritis. Via humoral messengers (eg, interleukin-6, vascular endothelial growth factor) and connections between the subchondral bone and the articular cartilage, such as microcracks or invading blood vessels, activated osteoblasts may stimulate articular chondrocytes to promote chondrocyte hypertrophy and cartilage angiogenesis and mineralization, leading to pathological remodeling of the osteochondral unit in osteoarthritis. ${ }^{21}$

\section{Current options to improve articular cartilage repair}

For the treatment of focal articular cartilage defects, conservative approaches solely aim at reducing pain. Surgical options for chondral lesions include marrow stimulation procedures such as subchondral drilling, ${ }^{22}$ microfracture, ${ }^{23}$ and abrasion arthroplasty. ${ }^{24}$ These measures establish a communication of the cartilage defect with the bone marrow, allowing MSCs from the underlying cavity to migrate into the defect. ${ }^{25}$ The transplantation of isolated and expanded autologous chondrocytes in the absence or presence of supportive biodegradable matrices (autologous chondrocyte implantation) ${ }^{26}$ is another operative option for focal chondral defects. For deep osteochondral defects, established reconstructive surgical therapies include the transplantation of osteochondral cylinders from uninjured, lesser weight-bearing areas of the joint ${ }^{27}$ or subchondral bone grafts combined with autologous chondrocyte implantation. ${ }^{28}$
Regarding the treatment of osteoarthritis, conservative measures comprise (but are not limited to) nonpharmacological options, such as weight reduction, land-based and aquatic exercises, or physical therapy, and pharmacological approaches based on nonsteroidal anti-inflammatory drugs, opioid analgesics, or intra-articular corticosteroid or hyaluronic acid injections. ${ }^{29,30}$ Surgical options for osteoarthritis include osteotomies to transfer the weight load from the damaged compartment to undamaged areas, and unicompartmental or total joint replacement.

However, no conservative or operative treatment procedure for either focal or generalized articular cartilage deterioration promotes a restitutio ad integrum; hyaline cartilage is never obtained and the fibrocartilaginous repair tissues are incapable of withstanding mechanical stresses over time. This shortcoming in patient care urgently necessitates the quest for novel treatment options for articular cartilage defects.

\section{Value of stem cell manipulation for knee cartilage repair}

Application of progenitor cells, especially MSCs, is an attractive strategy to improve the reparative processes in sites of cartilage damage compared with the implantation of differentiated cells like articular chondrocytes. ${ }^{31}$ MSCs have a reliable potential for differentiation (plasticity) into cells of the mesodermal lineage (chondrocytes, osteoblasts, adipocytes). ${ }^{32,33}$ They also display critical homing, trophic, and immunomodulatory activities ${ }^{34-37}$ that may favorably influence the fate and activities of unaffected cells in the surrounding cartilage upon implantation in sites of cartilage damage or injury.

MSCs can be easily extracted from various tissues (eg, bone marrow, adipose tissue, synovial membrane) and expanded under specific culture conditions that allow for extensive testing prior to implantation. The Mesenchymal and Tissue Stem Cell Committee of the International Society for Cellular Therapy has defined the following minimal set of standard criteria for uniform characterization of MSCs: they must be plastic-adherent cells when maintained in standard culture conditions; they must express CD105, CD73, and CD90; they must lack surface expression of CD45, CD34, CD14 (CD11b), CD79 $\alpha$ (CD19), and HLA-DR; and must be capable of differentiating to cells of the mesodermal lineage (chondrocytes, osteoblasts, adipocytes). ${ }^{38,39}$

\section{Bone marrow-derived MSCs}

Bone marrow-derived MSCs have been a focus of stem cell research in light of their relative ease of isolation and 
expansion and of their high potential for differentiation. ${ }^{40}$ Chondrogenesis has been conveniently achieved in highdensity (aggregate) cultures in the presence of a defined medium that includes dexamethasone and transforming growth factor beta (TGF- $\beta$ ). ${ }^{41,42}$ However, an inverse correlation between age and differentiation potential of bone marrow-derived MSCs has been reported, being a challenge for application in elderly patients. ${ }^{43}$ Nevertheless, proofof-concept for the use of bone marrow-derived MSCs in vivo has been demonstrated in animal models of articular cartilage defects and osteoarthritis (rat, rabbit, pig, sheep, horse), showing improved repair of lesions compared with conditions where cells were not provided. ${ }^{44-59}$

\section{Adipose-derived MSCs}

Adipose tissue has been also an important source of MSCs. Compared with bone marrow-derived MSCs, adipose-derived MSCs from lipoaspirates are acquired using a less invasive procedure and in larger amounts. ${ }^{60,61}$ Adipose-derived MSCs can commit toward the chondrogenic, osteogenic, adipogenic, myogenic, and neurogenic lineages, ${ }^{62}$ although they display some differences from bone marrow-derived MSCs. Adipose-derived MSCs are smaller, have different gene expression and cell surface marker profiles, and can undergo a higher number of passages before senescence, showing enhanced rates of proliferation. ${ }^{61,63-67}$ While adipose-derived MSCs show lesser responses to TGF- $\beta$-induced chondrogenesis, ${ }^{68}$ efficient differentiation has been nevertheless established by addition of bone morphogenetic protein $6 .{ }^{64}$ These cells have also been successfully employed to target cartilage defects and osteoarthritis cartilage in vivo, revealing improved outcomes for cartilage repair. ${ }^{51,52,69-78}$

\section{Synovial-derived MSCs}

Successful extraction of MSCs from the synovial membrane has been reported by harvesting of the synovial membrane via arthroscopy in a low invasive way with minimal complications at the donor site. ${ }^{79,80}$ Synovial-derived MSCs have higher proliferative and chondrogenic capacities than other MSCs especially when incubated with bone morphogenetic protein $2 .^{80-82}$ Of note, administration of synovial-derived MSCs has also been performed in vivo, leading to enhanced cartilage repair. ${ }^{51,52,83-87}$ Still, many issues need to be addressed regarding the value of synovial-derived MSCs due to a certain persistence of fibroblastic features and induction of hypertrophic gene expression profiles upon chondrogenic commitment. ${ }^{80}$

\section{Alternative sources of progenitor cells}

MSCs have also been isolated from the periosteum, trabecular bone, umbilical cord blood, amniotic fluid, Wharton's jelly, and skeletal muscle. Periosteum progenitor MSCs ${ }^{88}$ and umbilical cord blood $\mathrm{MSCs}^{89}$ can both be induced towards the chondrogenic lineage in the presence of TGF- $\beta$. Periosteum progenitor MSCs have been successfully applied to repair models of cartilage defects in vivo. ${ }^{52,57,90}$ However, while periosteum progenitor MSCs are phenotypically stable and easily expanded in culture, ${ }^{91}$ their use is limited by the reduced availability of donor material and the complexity of the surgical procedure of extraction. ${ }^{91}$ Umbilical cord blood, in contrast with bone marrow or adipose tissue, possesses a lower isolation efficiency but expansion is more effective. ${ }^{92}$ Still, administration of these cells did not allow for the proper repair of cartilage defects in animal models while triggering an inflammatory reaction in the synovium. ${ }^{59}$ Muscle-derived stem cells exhibit a broad differentiation capacity similar to that of bone marrow-derived MSCs. ${ }^{93}$ Evaluations in vivo revealed that muscle-derived stem cells have the potential to improve the repair of cartilage defects. ${ }^{51,52,94}$ However, their capability is sex-dependent (male muscle-derived stem cells have a higher potential for chondrogenic differentiation and cartilage regeneration). ${ }^{95}$

Interestingly, peripheral blood MSCs have been also evaluated as an alternative source of cells for transplantation $^{96-98}$ because of their ease of harvest and potential for differentiation, and implantation of such cells allowed for good repair of cartilage defects in vivo. ${ }^{99}$ Of note, investigation into the value of other types of progenitor cells for cartilage repair is actively ongoing, including work on embryonic stem cells and induced pluripotent stem cells. Embryonic stem cells and induced pluripotent stem cells may provide universal, unlimited sources of cells with reparative and regenerative capabilities for cartilage lesions because they have a potential for indefinite undifferentiated proliferation and can be induced towards chondrocyte differentiation. ${ }^{100-107}$ Embryonic stem cells have already been used to enhance the healing of cartilage defects in vivo ${ }^{108-110}$ and to allow for the production of a cartilage matrix capable of integrating with defects in human arthritic joint cartilage. ${ }^{111}$ However, use of embryonic stem cells remains largely controversial for ethical reasons to do with the harvesting of cells from human embryos, and due to safety issues because their use is associated with immune rejection problems and with the formation of teratomas. ${ }^{112}$ Active experimental work is ongoing with induced pluripotent stem cells that can be 
generated from the patient's own somatic cells, thus avoiding potential immune rejection and ethical issues related to the use of embryonic stem cells. Induced pluripotent stem cells are usually generated by reprogramming of differentiated cells such as fibroblasts by gene transfer of multiple transcription factors or using chemical methods. ${ }^{113-116}$ So far, induced pluripotent stem cells have been applied to cartilage defect models in vitro, leading to production and integration of a structurally and biomechanically adapted cartilage matrix. ${ }^{117}$ Nevertheless, there are major challenges regarding the clinical use of induced pluripotent stem cells, including the risks of teratoma formation and of tumorigenesis by possible integration (insertional mutagenesis) of retroviral vectors that deliver reprogramming genes (among which is the oncogenic Myc factor). ${ }^{118-120}$

\section{Principles of stem cell delivery for cartilage repair}

Different aspects have to be considered for the development of a stem cell-based protocol that can effectively and appropriately enhance the reparative processes in sites of cartilage damage, including the selection of components to provide in the lesion and the choice of the most suitable approach for implantation.

\section{Therapeutic composition}

The components for optimal cartilage repair based on the delivery of stem cells include the source of cells itself, the (recommended) presence of an instructive biomaterial for cell seeding and containment, and possible biological supplements (Figure 1B).

\section{Cells}

Among the populations of stem cells evaluated so far for their ability to enhance cartilage repair, as described above, bone marrow-derived MSCs (isolated cells or cell concentrates), adipose-derived MSCs, umbilical cord blood MSCs, and peripheral blood MSCs have been employed and tested in patients, depending on their availability and ease of preparation (Tables 1 and 2). Details of the trials are discussed later.

\section{Biomaterials}

Current approaches for knee cartilage repair focus on the use of scaffolds that provide a three-dimensional environment for guiding the cells and supporting growth of a cartilaginous repair tissue. An important advantage of using scaffolds for cell delivery (besides containment of the implanted cells inside the lesion) is that biomaterials can act as barriers for fibroblast invasion of the graft that may otherwise induce fibrous repair. ${ }^{121,122}$

To date, among the biomaterials used to deliver stem cells in patients with cartilage defects or osteoarthritis, hydrogels and solid scaffolds based on natural polymers have mainly been exploited (Tables 1 and 2). Hydrogels are polymeric networks consisting of crosslinked hydrophilic polymers with

Table I Current stem cell-based options for knee cartilage defects

\begin{tabular}{|c|c|c|c|c|c|}
\hline Cells & Environment & Approach & Patient follow-up & Results & Reference \\
\hline \multirow[t]{13}{*}{ BMSCs } & Cells, FG & $\mathrm{S}$ & $\mathrm{n}=36$ (24 months) & Clinical improvements, hyaline-like tissue & 205 \\
\hline & Cells, PRFG & $\mathrm{S}$ & $\mathrm{n}=5$ (one year) & Clinical improvements, hyaline-like tissue & 202 \\
\hline & Cells, HA & $\mathrm{I}, \mathrm{S}$ & $\mathrm{n}=70$ (24 months) & Clinical improvements & 195 \\
\hline & \multirow[t]{3}{*}{ Cells, collagen gel } & \multirow[t]{3}{*}{$\mathrm{S}$} & $\mathrm{n}=2(5$ years $)$ & Clinical improvements, fibrocartilaginous & 209 \\
\hline & & & $\mathrm{n}=\mathrm{I}$ (one year) & \multirow[t]{2}{*}{ to hyaline-like tissue } & 204 \\
\hline & & & $\mathrm{n}=3$ (27 months) & & 210 \\
\hline & Cells, collagen scaffold & $\mathrm{S}$ & $\mathrm{n}=2$ (3I months) & Clinical improvements, fibrocartilaginous tissue & 203 \\
\hline & Cells, IP-CHA & S & $\mathrm{n}=\mathrm{l}$ (none) & Hyaline-like tissue & 199 \\
\hline & Concentrate, FG & $\mathrm{S}$ & $\mathrm{n}=14$ (12 months) & Clinical improvements & 208 \\
\hline & Concentrate, PRFG and HA & $\mathrm{S}$ & $\mathrm{n}=20$ (24 months) & Clinical improvements, hyaline-like tissue & 200 \\
\hline & Concentrate, collagen & $\mathrm{S}$ & $\mathrm{n}=54$ (5 years) & Clinical improvements, fibrocartilaginous & 207 \\
\hline & membrane & & $\mathrm{n}=2 \mathrm{I}$ (5 years) & to hyaline-like tissue & 206 \\
\hline & Concentrate, AMIC & $\mathrm{S}$ & $\mathrm{n}=5$ ( 12 months) & Fibrocartilaginous to hyaline-like tissue & 201 \\
\hline \multirow[t]{4}{*}{ PBMSCs } & Cells & I & $\mathrm{n}=52(6$ years $)$ & Clinical improvements & 198 \\
\hline & \multirow[t]{2}{*}{ Cells, HA } & \multirow[t]{2}{*}{$\mathrm{I}$} & $\mathrm{n}=5$ (3 months) & \multirow[t]{2}{*}{ Hyaline-like tissue } & 196 \\
\hline & & & $\mathrm{n}=25$ (24 months) & & 197 \\
\hline & Cells, collagen membrane & $S$ & $\mathrm{n}=25(5$ years $)$ & $\begin{array}{l}\text { Clinical improvements, fibrocartilaginous } \\
\text { to hyaline-like tissue }\end{array}$ & 206 \\
\hline
\end{tabular}

Abbreviations: BMSCs, bone marrow-derived mesenchymal stem cells; FG, fibrin glue; PRFG, platelet-rich fibrin glue; HA, hyaluronic acid; IP-CHA, interconnected porous hydroxyapatite ceramic; AMIC, autologous matrix-induced chondrogenesis (collagen type I/III matrix); I, injective treatment; S, surgical treatment; PBMSCs, peripheral blood marrow-derived mesenchymal cells. 
Table 2 Current stem cell-based options for knee osteoarthritis

\begin{tabular}{|c|c|c|c|c|c|}
\hline Cells & Environment & Approach & Patient follow-up & Results & References \\
\hline \multirow[t]{6}{*}{ BMSCs } & Cells & 1 & $\mathrm{n}=\mathrm{I}$ (6 months) & Clinical improvements & 211 \\
\hline & & & $\mathrm{n}=4$ ( 12 months $)$ & & 212 \\
\hline & & & $\mathrm{n}=6$ ( 12 months $)$ & & 213 \\
\hline & & & $\mathrm{n}=12$ (12 months) & & 214 \\
\hline & Cells, collagen gel & $S$ & $\mathrm{n}=12$ (16 months) & Clinical improvements, hyaline-like tissue & 219 \\
\hline & Concentrate & 1 & $\mathrm{n}=25$ (6 months) & Clinical improvements & 215 \\
\hline \multirow[t]{3}{*}{ ASCs } & Cells, PRP & I & $\mathrm{n}=25$ (16 months) & Clinical improvements & 216 \\
\hline & & & $\mathrm{n}=18$ (24 months) & & 217 \\
\hline & Cells, PRP and HA & I & $\mathrm{n}=2$ (3 months) & Clinical improvements & 218 \\
\hline
\end{tabular}

Abbreviations: ASCs, adipose-derived stem cells; BMSCs, bone marrow-derived mesenchymal stem cells; PRP, platelet-rich plasma; HA, hyaluronic acid; I, injective treatment; S, surgical treatment.

good biocompatibility, high permeability for oxygen and nutrients, and ease of cell encapsulation, which results in their uniform distribution. Fibrin, a protein involved in the clotting of blood, has been broadly employed to encapsulate cells ${ }^{123}$ through ligation with integrin receptors. Fibrin is usually provided in the form of gels or glues that are biocompatible and biodegradable. Hyaluronic acid, or hyaluronan, has been widely used due to its large natural presence in the extracellular matrix and its pivotal role in cartilage homeostasis. ${ }^{124,125}$ Collagen-based biomaterials have also been applied extensively for cartilage regeneration ${ }^{126}$ due to the strength and stability of this matrix protein. They can be processed as gels, membranes, sponges, or foam, being subjected to enzymatic degradation. Alternatively, three-dimensional solid porous scaffolds such as ceramics may confer mechanical stability immediately upon implantation, providing scaffolding to support the growth of cartilaginous repair tissue and filling of the lesions. ${ }^{127,128}$ Still, the relatively poor integration of the different biomaterials with the surrounding cartilage remains a key problem that must be solved to permit continuity between the newly formed cartilage and the native one, long-term healing, and biomechanical competence. ${ }^{129-134}$ For a more substantial analysis of the most currently used scaffolds for cartilage tissue engineering, we refer to several comprehensive reviews of the literature. ${ }^{135-137}$

\section{Biological supplementation}

Although there is no specific clinical information on the benefits of supplementing stem cell-based therapies with biological factors as yet, active experimental research is ongoing to determine the potential benefits of various molecules for repair or regeneration of damaged cartilage.

Candidate factors with therapeutic value for the remodeling of articular cartilage can be provided to stem cells seeded in scaffolds in a recombinant form or via gene transfer using nonviral or viral (adenoviral, retroviral, lentiviral, recombinant adeno-associated viral) vectors. ${ }^{2,31,138}$ Growth factors are among the most studied agents, including TGF- $\beta^{80,129,139-152}$ the bone morphogenetic proteins (2, 4, 7; also as a BMP-4/sFlt1 combination to block angiogenesis), ${ }^{129,141,153-159}$ cartilage-derived morphogenetic protein $1,{ }^{152,160}$ insulin-like growth factor I ${ }^{146}$ platelet-derived growth factor, ${ }^{143}$ and connective tissue growth factor. ${ }^{161}$ Other classes of molecules have also been evaluated, including specific transcription factors (SOX5, SOX6, SOX9, ZNF145) $)^{162-165}$ and antiapoptotic proteins (Bcl-xL). ${ }^{166}$ It is interesting to note that most of this laboratory work so far has been performed in models of cartilage defects ${ }^{129,139-154,158-167}$ and relatively few in experimental osteoarthritis, ${ }^{155-157,164}$ possibly because of the availability of very distinct animal models of osteoarthritis (reflecting the complexity of this disorder) that are in general more arduous to generate and monitor than those for focal defects. ${ }^{168,169}$ It remains to be evaluated, however, whether such biological strategies will be feasible in the operating room and applicable in patients. In light of the report of a patient who died after being enrolled in an arthritis gene therapy trial, ${ }^{170}$ the use of gene transfer vectors remains a critical issue for clinical translation to treat nonlethal disorders such as cartilage defects and osteoarthritis. Nevertheless, while first placed on clinical hold, the study was cleared and allowed to proceed with minor changes by the US Food and Drug Administration because the death was not attributed to the gene treatment, showing that such an approach may still be considered as part of the clinical tools for cartilage repair.

\section{Treatment approaches}

Stem cell-based treatments for focal defects or for generalized osteoarthritis can be performed by intra-articular injection or via surgical arthrotomy with cell transplantation at the site of the lesion in conjunction (or not) with a periosteal or synovial flap. 


\section{Injective treatment}

This technique involves administration of a suspension containing therapeutically active stem cells by intra-articular injection. The procedure of intra-articular injection itself is abundantly described and has been established for decades, ${ }^{171-178}$ is technically easy to perform because it is less invasive, and is suitable for outpatients. Also, the risks associated with stem cell injections are less severe compared with an open surgical treatment. On the other side, delivery of cells using this approach cannot be achieved precisely within the lesion and cells might engraft and populate other nontarget tissues. Therefore, injections may have more value to treat generalized articular cartilage degeneration, as in osteoarthritis.

\section{Surgical treatment}

Surgical cell transplantation necessitates an arthrotomy with exposure of the joint surface. Numerous operative approaches to the knee joint and various indications have been described for this purpose. ${ }^{179-186}$ These may be adapted for surgical transplantation of stem cells into cartilage lesions. However, this procedure is prone to significant neurovascular complications and a higher postoperative infection rate compared with injective treatments, and usually requires several days of hospital stay. Still, it allows for very precise delivery of cells to the site of injury. Supplementation of the procedure with an instructive biomaterial that can further contain the implanted seeded cells is feasible with this technique. For these reasons, surgical delivery of stems cells is more adapted to treat focal defects of the joint surface.

Also noteworthy is that both types of procedures can be combined with surgical options currently employed for focal defects or generalized cartilage lesions such as arthroscopic debridement, marrow stimulation procedures, or osteotomies to unload injured joint compartments. Importantly, and in contrast with the conventional two-step autologous chondrocyte implantation procedure, transplantation of stem cells can be designed as a single-step protocol, although under specific preparative conditions (see below).

\section{Current clinical applications of stem cells for knee cartilage repair}

Stem cell therapy is actually widely employed in the clinic to treat focal cartilage defects and osteoarthritis of the knee using both injective and surgical treatments. Various scalebased methods are available to monitor the outcomes of articular cartilage repair in patients. The Short Form (SF-36) health survey monitors health status and compares disease burdens regarding vitality, physical functioning, bodily pain, general health perceptions, physical role functioning, emotional role functioning, social role functioning, and mental health. ${ }^{187}$ The visual analog scale is a subjective linear psychometric response scale on which patients specify their level of pain intensity by indicating a position along a continuous (analog) line between two endpoints. Results are given as percentages where higher values indicate more severe pain. ${ }^{188}$ The International Knee Documentation Committee (IKDC) developed an objective scale (effusion, motion, ligament laxity, crepitus, harvest site pathology, one leg hop test, radiographic findings $)^{189}$ and a subjective score (severity of symptoms, limitations in sports activities, and joint function). ${ }^{190}$ The Lysholm knee scoring scale evaluates limping, the use of a support, joint locking and instability, pain, swelling, stair climbing, and squatting. ${ }^{191}$ The Knee Injury and Osteoarthritis Outcome Score (KOOS) assesses symptoms, pain, function in daily living, sports, recreational activities, and quality of life. ${ }^{192}$ The cartilage injury evaluation package of the International Cartilage Repair Society (ICRS, cartilage.org) includes the ICRS injury questionnaire and subjective knee evaluation form (both patient-reported), and the ICRS knee surgery history registration, knee examination form, articular cartilage injury mapping system, articular cartilage injury classification, osteochondritis dissecans classification, and the cartilage repair assessment system (all surgeon-reported). Of note, the ICRS subjective knee evaluation form and objective knee examination form correspond to the subjective and objective IKDC scores, respectively. The Hospital for Special Surgery knee rating scale is based on the individual criteria of pain, function, range of motion, muscle strength, flexion deformity, and instability. ${ }^{193}$ The Western Ontario and McMaster Universities Osteoarthritis Index is the most commonly used instrument for patients with knee osteoarthritis, and includes questions related to difficulties during activities of daily living, pain, and stiffness. ${ }^{194}$

\section{Applications for articular cartilage defects Injective treatments}

Intra-articular stem cell injections for the clinical treatment of focal lesions so far have only been investigated in conjunction with marrow stimulation procedures, based on the use of bone marrow-derived MSCs ${ }^{195}$ and peripheral blood MSCs $^{196-198}$ (Table 1).

Injection of bone marrow-derived MSCs during microfracture treatment yielded significant improvements in the SF-36, IKDC subjective knee evaluation form, and Lysholm 
knee scale in patients after 2 years, while magnetic resonance imaging (MRI) revealed good defect filling and integration of the repair tissue. ${ }^{195}$

Injection of peripheral blood MSCs allowed improvement in the KOOS, Lysholm score, visual analog scale, and KOOS pain scale in patients with ICRS grade 3 or 4 lesions for up to 6 years. ${ }^{198}$ Moreover, second-look arthroscopies of subchondral drilling of ICRS grade 3 and 4 lesions in patients combined with five weekly injections of peripheral blood MSCs in hyaluronic acid starting one week postoperatively revealed a well-integrated repair tissue of fibrocartilaginous and hyaline-like cartilaginous aspect without delamination or hypertrophy after 3 months compared with hyaluronic acid treatment alone. ${ }^{196,197}$ Evaluations with core biopsies and MRI scans after 18 months further revealed improved cartilage repair in the presence of peripheral blood MSCs.

\section{Surgical treatments}

Surgical stem cell transplantation in cartilage defects has been developed in association with the use of matrices or biomaterials to deliver bone marrow-derived MSCs (fibrin glue, hyaluronic acid, collagen matrices and scaffolds, hydroxyapatite ceramic) ${ }^{199-210}$ and peripheral blood MSCs (collagen matrices and scaffolds ${ }^{206}$ ) (Table 1).

Transplantation of bone marrow-derived MSCs as isolated cells or marrow concentrates using fibrin glue er,208 $^{20 r}$ platelet-rich fibrin gel $^{202}$ revealed clinical and subjective improvements in patients for 1-2 years postoperatively using the ICRS cartilage injury evaluation package, IKDC subjective knee examination form, Lysholm knee scale, revised Hospital for Special Surgery knee grading scale, and ICRS arthroscopic scores. This was accompanied by formation of a hyaline-like repair tissue similar to first-generation autologous chondrocyte implantation ${ }^{205}$ and with MRI findings showing surfaces with good defect filling ${ }^{202}$ and correct contours and continuity with the native cartilage, ${ }^{202,208}$ and without changes in the subchondral bone. ${ }^{208}$ Similar approaches using isolated bone marrow-derived MSCs or marrow concentrates in hyaluronic acid yielded clinical and subjective improvements in patients 2 years postoperatively using the SF-36, IKDC subjective knee examination form, KOOS, and Lysholm knee scale. ${ }^{195,200}$ Good subchondral and cartilage repair was also documented by scoring of cartilage repair using MRI evaluation. ${ }^{200}$ Alternatively, transplantation of isolated bone marrow-derived MSCs or marrow concentrates in collagen-derived elements (gel, scaffold, membrane, matrix) led to improved clinical outcomes in patients between 6 months and 5 years postoperatively using the KOOS functional and pain scale, visual analog scale, IKDC, and Lysholm score. ${ }^{203,206,207}$ Second-look arthroscopy revealed good defect filling with incorporation in the adjacent cartilage, ${ }^{203}$ and formation of a repair tissue of fibrocartilaginous ${ }^{209,210}$ or even hyaline-like nature. ${ }^{204} \mathrm{MRI}$ evaluations also showed reconstruction of the cartilaginous surface and good integration of the repair tissue, ${ }^{206,207}$ while core biopsies yielded hyaline-like matrix or a mixture of hyaline and fibrocartilage. ${ }^{201}$ Finally, implantation of bone marrow-derived MSCs in an interconnected porous hydroxyapatite ceramic allowed for cartilage and bone regeneration in patients at second-look arthroscopy. ${ }^{199}$

Similarly, transplantation of peripheral blood MSCs in a collagen membrane ${ }^{206}$ in patients with ICRS grade 3 and 4 lesions yielded significant clinical improvements at one and 5 years postoperatively using the KOOS and Lysholm functional scores, the visual analog scale, and the KOOS pain scale. MRI evaluations also showed satisfactory reconstruction of the cartilaginous surface and good integration of the repair tissue.

Other protocols are ongoing (clinicaltrials.gov), such as those based on the transplantation of isolated bone marrowderived MSCs or marrow concentrates (NCT00885729, NCT00891501, NCT00850187211-213 with a collagen I scaffold, NCT01159899214 with a protein matrix and a collagen hydroxyapatite scaffold), adipose-derived stem cells (NCT01399749) ${ }^{215}$, and umbilical cord blood MSCs (NCT01041001, NCT01626677, NCT01733186 216-218 with CARTISTEM $^{\circledR}$ and sodium hyaluronate), although the outcomes have yet to be published.

\section{Applications for osteoarthritis Injective treatments}

Intra-articular stem cell injections for osteoarthritis have been investigated so far using bone marrow-derived $\mathrm{MSCs}^{219-223}$ and adipose-derived stem cells ${ }^{224-226}$ (Table 2).

Injection of isolated bone marrow-derived $\mathrm{MSCs}^{219-222}$ or of marrow aspirates via arthroscopic debridement ${ }^{223}$ allowed improvement in visual analog scale pain scores and range of motion ${ }^{219-223}$ as well as osteoarthritis outcome scores ${ }^{223}$ in patients at 6-12 months postoperatively. Furthermore, increases in cartilage growth and thickness with decreases in the size of poor cartilage and edematous subchondral bone were documented on MRI and by T2 relaxation measurements. ${ }^{219,221,222}$

Injection of adipose-derived stem cells using plateletrich plasma and arthroscopic debridement ${ }^{224,225}$ or plateletrich plasma with hyaluronic acid ${ }^{226}$ yielded improved 
clinical outcomes using the Western Ontario and McMaster Universities Osteoarthritis Index, Lysholm, and visual analog scale pain score in patients between 16 months and 2 years, with an enhanced whole-organ cartilage MRI score 224,225 and improved subjective pain score and functional status in patients 3 months postoperatively, along with increased cartilage thickness on MRI. ${ }^{226}$

\section{Surgical treatments}

In line with the fact that surgical stem cell transplantation is more suitable for focal defects than for osteoarthritis, only one study by Wakitani et $\mathrm{al}^{227}$ has addressed this approach to date (Table 2). This group evaluated the benefits of transplanting bone marrow-derived MSCs with a collagen gel in patients after high tibial osteotomy. Clinical evaluations prior to and after surgery (up to 16 months) using the Hospital for Special Surgery knee rating scale revealed no difference between the cell-treated and cell-free group. However, arthroscopic and histological grading of the repair tissues on core biopsies performed at 7 and 42 weeks after treatment showed improved scores in the cell-treated group at both time points.

Other protocols are ongoing (clinicaltrials.gov), and include those based on transplantation of isolated bone marrow-derived MSCs or marrow concentrates (NCT01152125, NCT01485198, NCT01895413, NCT01931007, NCT01879046228-231 by arthroplasty, ie, ARTHROSTEM, NCT01448434 ${ }^{232}$ and NCT01453738 $8^{233}$ with Plasmalyte-A and hyaluronan, NCT01459640 234 with hyaluronic acid, ie, Orthovisc ${ }^{\circledR}$ [Anika Therapeutics, Inc, Bedford, MA, USA]), adipose-derived stem cells (NCT01300598, NCT01585857, NCT01739504, NCT01809769, NCT01885832, NCT01947348, ${ }^{235-241}$ NCT01879046 by arthroplasty, ie, ARTHROSTEM), and peripheral blood MSCs (NCT01879046 by arthroplasty, ie, ARTHROSTEM), although the outcomes have not as yet been published.

\section{Conclusion and perspectives}

Stem cell implantation is a promising approach for cartilage repair in the knee and is already in clinical use for focal defects and generalized osteoarthritis. However, more controlled studies are needed to achieve both efficacy (appropriate biological and biomechanical properties) and safety in patients, given that cartilage lesions are not lifethreatening disorders. There are still some issues regarding the effective use of stem cells, including their reduced potentiality with age and disease, like in osteoarthritis with an inflammatory environment, the effects of cellular aging upon sequential expansion, and the critical questions of production of fibrocartilage instead of hyaline cartilage in the lesion and of terminal differentiation with cell hypertrophy and mineralization leading to the replacement of cartilage by bone. Regarding the safe administration of stem cells, there is a potential risk of colonization of nontarget tissues, possible induction or stimulation of tumorigenesis, and transmission of infection, as well as the use of human (allogeneic) or animal serum-derived agents during cell expansion.

Further, standardization of the implantation procedure needs to be addressed from the clinical point of view, depending on the age and background of patients with possible associated pathologies, on the type, size, and localization of the lesion(s), on the length of follow-up, and on the methods used for assessment of cartilage repair. From a laboratory point of view, standardization is also necessary regarding the optimal source and amount of cells requested, the number of injections, the benefits of isolated cells versus cultureexpanded cells versus cell concentrates (ie, one-step versus two-step procedure) with specified conditions of preparation and maintenance, and the use of autologous versus allogeneic samples.

Nevertheless, despite these considerations, the clinical outcomes of the ongoing and available trials in patients are encouraging, showing the potential of stem cell therapy for cartilage repair upon further elaboration and appropriate optimization in line with the regulatory standards and legal requirements for production/manufacture, use, and application of biologics of the international drug regulatory frameworks, particularly the European Medicines Agency (ema.europa.eu) and the US Food and Drug Administration ( $\underline{\text { fda.gov). }}$.

\section{Disclosure}

The authors have no conflicts of interest to report in this work.

\section{References}

1. O'Driscoll SW. The healing and regeneration of articular cartilage. J Bone Joint Surg Am. 1998;80(12):1795-1812.

2. Cucchiarini M, Madry H. Gene therapy for cartilage defects. J Gene Med. 2005;7(12):1495-1509.

3. Hunziker EB, Michel M, Studer D. Ultrastructure of adult human articular cartilage matrix after cryotechnical processing. Microsc Res Tech. 1997;37(4):271-284.

4. Burr DB. Anatomy and physiology of the mineralized tissues: role in the pathogenesis of osteoarthrosis. Osteoarthritis Cartilage. 2004; 12 Suppl A:S20-S30.

5. Orth P, Cucchiarini M, Kohn D, Madry H. Alterations of the subchondral bone in osteochondral repair - translational data and clinical evidence. Eur Cell Mater. 2013;25:299-316.

6. Madry H, Cucchiarini M, Orth P. Gene therapy for cartilage repair. Cartilage. 2011;2(3):201-225. 
7. Hunziker EB. Articular cartilage repair: basic science and clinical progress. A review of the current status and prospects. Osteoarthritis Cartilage. 2002;10(6):432-463.

8. Furukawa T, Eyre DR, Koide S, Glimcher MJ. Biochemical studies on repair cartilage resurfacing experimental defects in the rabbit knee. J Bone Joint Surg Am. 1980;62(1):79-89.

9. Franke O, Durst K, Maier V, et al. Mechanical properties of hyaline and repair cartilage studied by nanoindentation. Acta Biomater. 2007;3(6): 873-881.

10. Caplan AI, Elyaderani M, Mochizuki Y, Wakitani S, Goldberg VM Principles of cartilage repair and regeneration. Clin Orthop Relat Res. 1997;342:254-269.

11. Caplan AI, Goldberg VM. Principles of tissue engineered regeneration of skeletal tissues. Clin Orthop Relat Res. 1999;367 Suppl: S12-S16.

12. Hunziker EB, Rosenberg LC. Repair of partial-thickness defects in articular cartilage: cell recruitment from the synovial membrane. J Bone Joint Surg Am. 1996;78(5):721-733.

13. Jackson DW, Lalor PA, Aberman HM, Simon TM. Spontaneous repair of full-thickness defects of articular cartilage in a goat model. A preliminary study. J Bone Joint Surg Am. 2001;83A(1):53-64.

14. Shapiro F, Koide S, Glimcher MJ. Cell origin and differentiation in the repair of full-thickness defects of articular cartilage. J Bone Joint Surg Am. 1993;75(4):532-553.

15. Mienaltowski MJ, Huang L, Frisbie DD, et al. Transcriptional profiling differences for articular cartilage and repair tissue in equine joint surface lesions. BMC Med Genomics. 2009;2:60-73.

16. Strauss EJ, Goodrich LR, Chen CT, Hidaka C, Nixon AJ. Biochemical and biomechanical properties of lesion and adjacent articular cartilage after chondral defect repair in an equine model. Am J Sports Med. 2005;33(11):1647-1653.

17. Anraku Y, Mizuta H, Sei A, et al. Analyses of early events during chondrogenic repair in rat full-thickness articular cartilage defects. J Bone Miner Metab. 2009;27(3):272-286.

18. Anraku Y, Mizuta H, Sei A, et al. The chondrogenic repair response of undifferentiated mesenchymal cells in rat full-thickness articular cartilage defects. Osteoarthritis Cartilage. 2008;16(8):961-964.

19. Gomoll AH, Farr J, Gillogly SD, Kercher J, Minas T. Surgical management of articular cartilage defects of the knee. J Bone Joint Surg Am 2010;92(14):2470-2490.

20. Sanchez C, Pesesse L, Gabay O, et al. Regulation of subchondral bone osteoblast metabolism by cyclic compression. Arthritis Rheum. 2012;64(4):1193-1203.

21. Henrotin Y, Pesesse L, Sanchez C. Subchondral bone and osteoarthritis: biological and cellular aspects. Osteoporos Int. 2012;23 Suppl 8: S847-S851.

22. Pridie KH. A method of resurfacing knee joints. Proceedings of the British Orthopaedic Association. J Bone Joint Surg Br. 1959;41 618.

23. Steadman JR, Rodkey WG, Rodrigo JJ. Microfracture: surgical technique and rehabilitation to treat chondral defects. Clin Orthop Relat Res. 2001;391 Suppl:S362-S369.

24. Johnson LL. Arthroscopic abrasion arthroplasty historical and pathologic perspective: present status. Arthroscopy. 1986;2(1):54-69.

25. Gomoll AH, Madry H, Knutsen G, et al. The subchondral bone in articular cartilage repair: current problems in the surgical management. Knee Surg Sports Traumatol Arthrosc. 2010;18(4):434-447.

26. Brittberg M, Lindahl A, Nilsson A, Ohlsson C, Isaksson O, Peterson L. Treatment of deep cartilage defects in the knee with autologous chondrocyte transplantation. N Engl J Med. 1994;331(14):889-895.

27. Hangody L, Kish G, Karpati Z, Udvarhelyi I, Szigeti I, Bely M. Mosaicplasty for the treatment of articular cartilage defects: application in clinical practice. Orthopedics. 1998;21(7):751-756.

28. Ochs BG, Muller-Horvat C, Albrecht D, et al. Remodeling of articular cartilage and subchondral bone after bone grafting and matrix-associated autologous chondrocyte implantation for osteochondritis dissecans of the knee. Am J Sports Med. 2011;39(4):764-773.
29. Kon E, Filardo G, Drobnic M, et al. Non-surgical management of early knee osteoarthritis. Knee Surg Sports Traumatol Arthrosc. 2012;20(3): 436-449.

30. Zhang W, Nuki G, Moskowitz RW, et al. OARSI recommendations for the management of hip and knee osteoarthritis: part III: Changes in evidence following systematic cumulative update of research published through January 2009. Osteoarthritis Cartilage. 2010;18(4): 476-499.

31. Cucchiarini M, Venkatesan JK, Ekici M, Schmitt G, Madry H. Human mesenchymal stem cells overexpressing therapeutic genes: from basic science to clinical applications for articular cartilage repair. Biomed Mater Eng. 2012;22(4):197-208.

32. Caplan AI. Mesenchymal stem cells. J Orthop Res. 1991;9(5): 641-650.

33. Pittenger MF, Mackay AM, Beck SC, et al. Multilineage potential of adult human mesenchymal stem cells. Science. 1999;284(5411): 143-147.

34. Aggarwal S, Pittenger MF. Human mesenchymal stem cells modulate allogeneic immune cell responses. Blood. 2005;105(4):1815-1822.

35. Caplan AI, Dennis JE. Mesenchymal stem cells as trophic mediators. J Cell Biochem. 2006;98(5):1076-1084.

36. Fong EL, Chan CK, Goodman SB. Stem cell homing in musculoskeletal injury. Biomaterials. 2011;32(2):395-409.

37. Liechty KW, MacKenzie TC, Shaaban AF, et al. Human mesenchymal stem cells engraft and demonstrate site-specific differentiation after in utero transplantation in sheep. Nat Med. 2000;6(11):1282-1286.

38. Dominici M, Le Blanc K, Mueller I, et al. Minimal criteria for defining multipotent mesenchymal stromal cells. The International Society for Cellular Therapy position statement. Cytotherapy. 2006;8(4): 315-317.

39. Horwitz EM, Le Blanc K, Dominici M, et al. Clarification of the nomenclature for MSC: The International Society for Cellular Therapy position statement. Cytotherapy. 2005;7(5):393-395.

40. Friedenstein AJ, Deriglasova UF, Kulagina NN, et al. Precursors for fibroblasts in different populations of hematopoietic cells as detected by the in vitro colony assay method. Exp Hematol. 1974;2(2): 83-92.

41. Mackay AM, Beck SC, Murphy JM, Barry FP, Chichester CO, Pittenger MF. Chondrogenic differentiation of cultured human mesenchymal stem cells from marrow. Tissue Eng. 1998;4(4):415-428.

42. Yoo JU, Barthel TS, Nishimura K, et al. The chondrogenic potential of human bone-marrow-derived mesenchymal progenitor cells. J Bone Joint Surg Am. 1998;80(12):1745-1757.

43. Baksh D, Yao R, Tuan RS. Comparison of proliferative and multilineage differentiation potential of human mesenchymal stem cells derived from umbilical cord and bone marrow. Stem Cells. 2007;25(6):1384-1392.

44. Al Faqeh H, Nor Hamdan BM, Chen HC, Aminuddin BS, Ruszymah BH. The potential of intra-articular injection of chondrogenic-induced bone marrow stem cells to retard the progression of osteoarthritis in a sheep model. Exp Gerontol. 2012;47(6):458-464.

45. Alfaqeh H, Norhamdan MY, Chua KH, Chen HC, Aminuddin BS, Ruszymah BH. Cell based therapy for osteoarthritis in a sheep model: gross and histological assessment. Med J Malaysia. 2008;63 Suppl A: 37-38.

46. Grigolo B, Lisignoli G, Desando G, et al. Osteoarthritis treated with mesenchymal stem cells on hyaluronan-based scaffold in rabbit. Tissue Eng Part C Methods. 2009;15(4):647-658.

47. Guo X, Wang C, Zhang Y, et al. Repair of large articular cartilage defects with implants of autologous mesenchymal stem cells seeded into beta-tricalcium phosphate in a sheep model. Tissue Eng. 2004; 10(11-12):1818-1829.

48. Im GI, Kim DY, Shin JH, Hyun CW, Cho WH. Repair of cartilage defect in the rabbit with cultured mesenchymal stem cells from bone marrow. J Bone Joint Surg Br. 2001;83(2):289-294.

49. Johnstone B, Yoo JU. Autologous mesenchymal progenitor cells in articular cartilage repair. Clin Orthop Relat Res. 1999;367 Suppl: S156-S162. 
50. Jung M, Kaszap B, Redohl A, et al. Enhanced early tissue regeneration after matrix-assisted autologous mesenchymal stem cell transplantation in full thickness chondral defects in a minipig model. Cell Transplant. 2009;18(8):923-932.

51. Koga H, Muneta T, Nagase T, et al. Comparison of mesenchymal tissues-derived stem cells for in vivo chondrogenesis: suitable conditions for cell therapy of cartilage defects in rabbit. Cell Tissue Res. 2008;333(2):207-215

52. Li Q, Tang J, Wang R, et al. Comparing the chondrogenic potential in vivo of autogeneic mesenchymal stem cells derived from different tissues. Artif Cells Blood Substit Immobil Biotechnol. 2011;39(1): $31-38$.

53. McIlwraith CW, Frisbie DD, Rodkey WG, et al. Evaluation of intraarticular mesenchymal stem cells to augment healing of microfractured chondral defects. Arthroscopy. 2011;27(11):1552-1561.

54. Murphy JM, Fink DJ, Hunziker EB, Barry FP. Stem cell therapy in a caprine model of osteoarthritis. Arthritis Rheum. 2003;48(12): 3464-3474

55. Nishimori M, Deie M, Kanaya A, Exham H, Adachi N, Ochi M. Repair of chronic osteochondral defects in the rat. A bone marrowstimulating procedure enhanced by cultured allogenic bone marrow mesenchymal stromal cells. J Bone Joint Surg Br. 2006;88(9): 1236-1244.

56. Radice M, Brun P, Cortivo R, Scapinelli R, Battaliard C, Abatangelo G. Hyaluronan-based biopolymers as delivery vehicles for bone-marrowderived mesenchymal progenitors. J Biomed Mater Res. 2000;50(2): 101-109.

57. Wakitani S, Goto T, Pineda SJ, et al. Mesenchymal cell-based repair of large, full-thickness defects of articular cartilage. J Bone Joint Surg Am. 1994;76(4):579-592.

58. Wakitani S, Yamamoto T. Response of the donor and recipient cells in mesenchymal cell transplantation to cartilage defect. Microsc Res Tech. 2002;58(1):14-18.

59. Yan H, Yu C. Repair of full-thickness cartilage defects with cells of different origin in a rabbit model. Arthroscopy. 2007;23(2):178-187.

60. Harris PB. Being old: a confrontation group with nursing home residents. Health Soc Work. 1979;4(1):152-166.

61. Peng L, Jia Z, Yin X, et al. Comparative analysis of mesenchymal stem cells from bone marrow, cartilage, and adipose tissue. Stem Cells Dev. 2008;17(4):761-773.

62. Zuk PA, Zhu M, Ashjian P, et al. Human adipose tissue is a source of multipotent stem cells. Mol Biol Cell. 2002;13(12):4279-4295.

63. De Ugarte DA, Alfonso Z, Zuk PA, et al. Differential expression of stem cell mobilization-associated molecules on multi-lineage cells from adipose tissue and bone marrow. Immunol Lett. 2003;89(2-3): 267-270.

64. Diekman BO, Rowland CR, Lennon DP, Caplan AI, Guilak F. Chondrogenesis of adult stem cells from adipose tissue and bone marrow: induction by growth factors and cartilage-derived matrix. Tissue Eng Part A. 2010;16(2):523-533.

65. Hennig T, Lorenz H, Thiel A, et al. Reduced chondrogenic potential of adipose tissue derived stromal cells correlates with an altered TGFbeta receptor and BMP profile and is overcome by BMP-6. J Cell Physiol. 2007;211(3):682-691.

66. Izadpanah R, Trygg C, Patel B, et al. Biologic properties of mesenchymal stem cells derived from bone marrow and adipose tissue. $J$ Cell Biochem. 2006;99(5):1285-1297.

67. Rider DA, Dombrowski C, Sawyer AA, et al. Autocrine fibroblast growth factor 2 increases the multipotentiality of human adipose-derived mesenchymal stem cells. Stem Cells. 2008;26(6):1598-1608.

68. Huang JI, Kazmi N, Durbhakula MM, Hering TM, Yoo JU, Johnstone B. Chondrogenic potential of progenitor cells derived from human bone marrow and adipose tissue: a patient-matched comparison. J Orthop Res. 2005;23(6):1383-1389.

69. Cui L, Wu Y, Cen L, et al. Repair of articular cartilage defect in nonweight bearing areas using adipose derived stem cells loaded polyglycolic acid mesh. Biomaterials. 2009;30(14):2683-2693.
70. Desando G, Cavallo C, Sartoni F, et al. Intra-articular delivery of adipose derived stromal cells attenuates osteoarthritis progression in an experimental rabbit model. Arthritis Res Ther. 2013;15(1):R22-R36.

71. Guercio A, Di Marco P, Casella S, et al. Production of canine mesenchymal stem cells from adipose tissue and their application in dogs with chronic osteoarthritis of the humeroradial joints. Cell Biol Int. 2012;36(2):189-194.

72. Jurgens WJ, Kroeze RJ, Zandieh-Doulabi B, et al. One-step surgical procedure for the treatment of osteochondral defects with adiposederived stem cells in a caprine knee defect: a pilot study. Biores Open Access. 2013;2(4):315-325.

73. Masuoka K, Asazuma T, Hattori H, et al. Tissue engineering of articular cartilage with autologous cultured adipose tissue-derived stromal cells using atelocollagen honeycomb-shaped scaffold with a membrane sealing in rabbits. $J$ Biomed Mater Res B Appl Biomater. 2006;79(1):25-34.

74. Nathan S, Das De S, Thambyah A, Fen C, Goh J, Lee EH. Cell-based therapy in the repair of osteochondral defects: a novel use for adipose tissue. Tissue Eng. 2003;9(4):733-744.

75. Oliveira JT, Gardel LS, Rada T, Martins L, Gomes ME, Reis RL. Injectable gellan gum hydrogels with autologous cells for the treatment of rabbit articular cartilage defects. J Orthop Res. 2010;28(9): 1193-1199.

76. ter Huurne M, Schelbergen R, Blattes R, et al. Antiinflammatory and chondroprotective effects of intraarticular injection of adiposederived stem cells in experimental osteoarthritis. Arthritis Rheum. 2012;64(11):3604-3613.

77. Toghraie F, Razmkhah M, Gholipour MA, et al. Scaffold-free adiposederived stem cells (ASCs) improve experimentally induced osteoarthritis in rabbits. Arch Iran Med. 2012;15(8):495-499.

78. Toghraie FS, Chenari N, Gholipour MA, et al. Treatment of osteoarthritis with infrapatellar fat pad derived mesenchymal stem cells in rabbit. Knee. 2011;18(2):71-75.

79. De Bari C, Dell'Accio F, Tylzanowski P, Luyten FP. Multipotent mesenchymal stem cells from adult human synovial membrane. Arthritis Rheum. 2001;44(8):1928-1942.

80. Fan J, Varshney RR, Ren L, Cai D, Wang DA. Synovium-derived mesenchymal stem cells: a new cell source for musculoskeletal regeneration. Tissue Eng Part B Rev. 2009;15(1):75-86.

81. Sakaguchi Y, Sekiya I, Yagishita K, Muneta T. Comparison of human stem cells derived from various mesenchymal tissues: superiority of synovium as a cell source. Arthritis Rheum. 2005;52(8):2521-2529.

82. Shirasawa S, Sekiya I, Sakaguchi Y, Yagishita K, Ichinose S, Muneta T. In vitro chondrogenesis of human synovium-derived mesenchymal stem cells: optimal condition and comparison with bone marrow-derived cells. J Cell Biochem. 2006;97(1):84-97.

83. Koga H, Shimaya M, Muneta T, et al. Local adherent technique for transplanting mesenchymal stem cells as a potential treatment of cartilage defect. Arthritis Res Ther. 2008;10(4):R84-R93.

84. Lee JC, Lee SY, Min HJ, et al. Synovium-derived mesenchymal stem cells encapsulated in a novel injectable gel can repair osteochondral defects in a rabbit model. Tissue Eng Part A. 2012;18(19-20):2173-2186.

85. Lee JC, Min HJ, Park HJ, Lee S, Seong SC, Lee MC. Synovial membrane-derived mesenchymal stem cells supported by platelet-rich plasma can repair osteochondral defects in a rabbit model. Arthroscopy. 2013;29(6):1034-1046.

86. Nakamura T, Sekiya I, Muneta T, et al. Arthroscopic, histological and MRI analyses of cartilage repair after a minimally invasive method of transplantation of allogeneic synovial mesenchymal stromal cells into cartilage defects in pigs. Cytotherapy. 2012;14(3):327-338.

87. Shimomura K, Ando W, Tateishi K, et al. The influence of skeletal maturity on allogenic synovial mesenchymal stem cell-based repair of cartilage in a large animal model. Biomaterials. 2010;31(31): 8004-8011.

88. Mara CS, Sartori AR, Duarte AS, Andrade AL, Pedro MA, Coimbra IB. Periosteum as a source of mesenchymal stem cells: the effects of TGFbeta3 on chondrogenesis. Clinics (Sao Paulo). 2011;66(3):487-492. 
89. Kern S, Eichler H, Stoeve J, Kluter H, Bieback K. Comparative analysis of mesenchymal stem cells from bone marrow, umbilical cord blood, or adipose tissue. Stem Cells. 2006;24(5):1294-1301.

90. Wakitani S, Yamamoto T. Response of the donor and recipient cells in mesenchymal cell transplantation to cartilage defect. Microsc Res Tech. 2002;58(1):14-18.

91. Hui JH, Li L, Teo YH, Ouyang HW, Lee EH. Comparative study of the ability of mesenchymal stem cells derived from bone marrow, periosteum, and adipose tissue in treatment of partial growth arrest in rabbit. Tissue Eng. 2005;11(5-6):904-912.

92. Bieback K, Kern S, Kluter H, Eichler H. Critical parameters for the isolation of mesenchymal stem cells from umbilical cord blood. Stem Cells. 2004;22(4):625-634.

93. Rosenbaum AJ, Grande DA, Dines JS. The use of mesenchymal stem cells in tissue engineering: a global assessment. Organogenesis. 2008;4(1):23-27.

94. Grande DA, Southerland SS, Manji R, Pate DW, Schwartz RE, Lucas PA. Repair of articular cartilage defects using mesenchymal stem cells. Tissue Eng. 1995;1(4):345-353.

95. Matsumoto T, Kubo S, Meszaros LB, et al. The influence of sex on the chondrogenic potential of muscle-derived stem cells: implications for cartilage regeneration and repair. Arthritis Rheum. 2008;58(12):3809-3819.

96. Chong PP, Selvaratnam L, Abbas AA, Kamarul T. Human peripheral blood derived mesenchymal stem cells demonstrate similar characteristics and chondrogenic differentiation potential to bone marrow derived mesenchymal stem cells. J Orthop Res. 2012;30(4):634-642.

97. Korbling M, Anderlini P. Peripheral blood stem cell versus bone marrow allotransplantation: does the source of hematopoietic stem cells matter? Blood. 2001;98(10):2900-2908.

98. Zvaifler NJ, Marinova-Mutafchieva L, Adams G, et al. Mesenchymal precursor cells in the blood of normal individuals. Arthritis Res. 2000;2(6):477-488.

99. Chang F, Ishii T, Yanai T, et al. Repair of large full-thickness articular cartilage defects by transplantation of autologous uncultured bonemarrow-derived mononuclear cells. J Orthop Res. 2008;26(1): 18-26.

100. Guzzo RM, Gibson J, Xu RH, Lee FY, Drissi H. Efficient differentiation of human iPSC-derived mesenchymal stem cells to chondroprogenitor cells. J Cell Biochem. 2013;114(2):480-490.

101. Hwang NS, Varghese S, Zhang Z, Elisseeff J. Chondrogenic differentiation of human embryonic stem cell-derived cells in arginine-glycineaspartate-modified hydrogels. Tissue Eng. 2006;12(9):2695-2706.

102. Koyama N, Miura M, Nakao K, et al. Human induced pluripotent stem cells differentiated into chondrogenic lineage via generation of mesenchymal progenitor cells. Stem Cells Dev. 2013;22(1):102-113.

103. Legg K. Stem cells: chondrogenesis induced from human embryonic stem cells. Nat Rev Rheumatol. 2010;6(2):66.

104. Oldershaw RA, Baxter MA, Lowe ET, et al. Directed differentiation of human embryonic stem cells toward chondrocytes. Nat Biotechnol. 2010;28(11):1187-1194

105. Thomson JA, Itskovitz-Eldor J, Shapiro SS, et al. Embryonic stem cell lines derived from human blastocysts. Science. 1998;282(5391): 1145-1147.

106. Vats A, Bielby RC, Tolley N, et al. Chondrogenic differentiation of human embryonic stem cells: the effect of the micro-environment. Tissue Eng. 2006;12(6):1687-1697.

107. Wei Y, Zeng W, Wan R, et al. Chondrogenic differentiation of induced pluripotent stem cells from osteoarthritic chondrocytes in alginate matrix. Eur Cell Mater. 2012;23:1-12.

108. Dattena M, Pilichi S, Rocca S, et al. Sheep embryonic stem-like cells transplanted in full-thickness cartilage defects. J Tissue Eng Regen Med. 2009;3(3):175-187.

109. Hwang NS, Varghese S, Lee HJ, et al. In vivo commitment and functional tissue regeneration using human embryonic stem cellderived mesenchymal cells. Proc Natl Acad Sci U S A. 2008;105(52): 20641-20646.
110. Toh WS, Lee EH, Guo XM, et al. Cartilage repair using hyaluronan hydrogel-encapsulated human embryonic stem cell-derived chondrogenic cells. Biomaterials. 2010;31(27):6968-6980.

111. Olee T, Grogan SP, Lotz M, Colwell CW Jr, Snyder E, D'Lima D. Repair of cartilage defects in arthritic tissue with differentiated human embryonic stem cells. Tissue Eng Part A. October 19, 2013. [Epub ahead of print.]

112. Blum B, Benvenisty N. Clonal analysis of human embryonic stem cell differentiation into teratomas. Stem Cells. 2007;25(8): $1924-1930$.

113. Hou P, LiY, Zhang X, et al. Pluripotent stem cells induced from mouse somatic cells by small-molecule compounds. Science. 2013;341(6146): 651-654.

114. Takahashi K, Tanabe K, Ohnuki M, et al. Induction of pluripotent stem cells from adult human fibroblasts by defined factors. Cell. 2007;131(5):861-872.

115. Takahashi K, Yamanaka S. Induction of pluripotent stem cells from mouse embryonic and adult fibroblast cultures by defined factors. Cell. 2006;126(4):663-676.

116. Yu J, Vodyanik MA, Smuga-Otto K, et al. Induced pluripotent stem cell lines derived from human somatic cells. Science. 2007;318(5858): 1917-1920

117. Diekman BO, Christoforou N, Willard VP, et al. Cartilage tissue engineering using differentiated and purified induced pluripotent stem cells. Proc Natl Acad Sci U S A. 2012;109(47):19172-19177.

118. Kim MJ, Son MJ, Son MY, et al. Generation of human induced pluripotent stem cells from osteoarthritis patient-derived synovial cells Arthritis Rheum. 2011;63(10):3010-3021.

119. Shafa M, Sjonnesen K, Yamashita A, et al. Expansion and long-term maintenance of induced pluripotent stem cells in stirred suspension bioreactors. J Tissue Eng Regen Med. 2012;6(6):462-472.

120. Yamashita A, Liu S, Woltjen K, et al. Cartilage tissue engineering identifies abnormal human induced pluripotent stem cells. Sci Rep. 2013;3:1978-1983

121. Frenkel SR, Toolan B, Menche D, Pitman MI, Pachence JM. Chondrocyte transplantation using a collagen bilayer matrix for cartilage repair. J Bone Joint Surg Br. 1997;79(5):831-836.

122. Iwasa J, Engebretsen L, Shima Y, Ochi M. Clinical application of scaffolds for cartilage tissue engineering. Knee Surg Sports Traumatol Arthrosc. 2009;17(6):561-577.

123. Ho W, Tawil B, Dunn JC, Wu BM. The behavior of human mesenchymal stem cells in 3D fibrin clots: dependence on fibrinogen concentration and clot structure. Tissue Eng. 2006;12(6):1587-1595.

124. Tognana E, Borrione A, De Luca C, Pavesio A. Hyalograft C: hyaluronan-based scaffolds in tissue-engineered cartilage. Cells Tissues Organs. 2007;186(2):97-103.

125. Toole BP. Hyaluronan in morphogenesis. Semin Cell Dev Biol. 2001;12(2):79-87.

126. Glowacki J, Mizuno S. Collagen scaffolds for tissue engineering. Biopolymers. 2008;89(5):338-344.

127. Guo X, Wang C, Duan C, et al. Repair of osteochondral defects with autologous chondrocytes seeded onto bioceramic scaffold in sheep. Tissue Eng. 2004;10(11-12):1830-1840.

128. Kandel RA, Grynpas M, Pilliar R, et al. Repair of osteochondral defects with biphasic cartilage-calcium polyphosphate constructs in a sheep model. Biomaterials. 2006;27(22):4120-4131.

129. Chen J, Chen H, Li P, et al. Simultaneous regeneration of articular cartilage and subchondral bone in vivo using MSCs induced by a spatially controlled gene delivery system in bilayered integrated scaffolds. Biomaterials. 2011;32(21):4793-4805.

130. Fan $\mathrm{H}, \mathrm{Hu} \mathrm{Y}$, Zhang $\mathrm{C}$, et al. Cartilage regeneration using mesenchymal stem cells and a PLGA-gelatin/chondroitin/hyaluronate hybrid scaffold. Biomaterials. 2006;27(26):4573-4580.

131. Gao J, Dennis JE, Solchaga LA, Goldberg VM, Caplan AI. Repair of osteochondral defect with tissue-engineered two-phase composite material of injectable calcium phosphate and hyaluronan sponge. Tissue Eng. 2002;8(5):827-837. 
132. Qi Y, Du Y, Li W, Dai X, Zhao T, Yan W. Cartilage repair using mesenchymal stem cell (MSC) sheet and MSCs-loaded bilayer PLGA scaffold in a rabbit model. Knee Surg Sports Traumatol Arthrosc. October 30, 2012. [Epub ahead of print.]

133. Shao XX, Hutmacher DW, Ho ST, Goh JC, Lee EH. Evaluation of a hybrid scaffold/cell construct in repair of high-load-bearing osteochondral defects in rabbits. Biomaterials. 2006;27(7): 1071-1080.

134. Zscharnack M, Hepp P, Richter R, et al. Repair of chronic osteochondral defects using predifferentiated mesenchymal stem cells in an ovine model. Am J Sports Med. 2010;38(9):1857-1869.

135. Daher RJ, Chahine NO, Greenberg AS, Sgaglione NA, Grande DA. New methods to diagnose and treat cartilage degeneration. Nat Rev Rheumatol. 2009;5(11):599-607.

136. Johnstone B, Alini M, Cucchiarini M, et al. Tissue engineering for articular cartilage repair - the state of the art. Eur Cell Mater. 2013;25:248-267.

137. Madry H, Rey-Rico A, Venkatesan JK, Johnstone B, Cucchiarini M. Transforming growth factor beta-releasing scaffolds for cartilage tissue engineering. Tissue Eng Part B Rev. August 12, 2013. [Epub ahead of print.]

138. Madry H, Cucchiarini M. Advances and challenges in gene-based approaches for osteoarthritis. J Gene Med. 2013;15(10):343-355.

139. Diao H, Wang J, Shen C, et al. Improved cartilage regeneration utilizing mesenchymal stem cells in TGF-betal gene-activated scaffolds. Tissue Eng Part A. 2009;15(9):2687-2698.

140. He CX, Zhang TY, Miao PH, et al. TGF-beta1 gene-engineered mesenchymal stem cells induce rat cartilage regeneration using nonviral gene vector. Biotechnol Appl Biochem. 2012;59(3):163-169.

141. Im GI, Lee JH. Repair of osteochondral defects with adipose stem cells and a dual growth factor-releasing scaffold in rabbits. $J$ Biomed Mater Res B Appl Biomater. 2010;92(2):552-560.

142. Ivkovic A, Pascher A, Hudetz D, et al. Articular cartilage repair by genetically modified bone marrow aspirate in sheep. Gene Ther. 2010;17(6):779-789.

143. Lee JM, Kim BS, Lee H, Im GI. In vivo tracking of mesechymal stem cells using fluorescent nanoparticles in an osteochondral repair model. Mol Ther. 2012;20(7):1434-1442.

144. Li B, Yang J, Ma L, Li F, Tu Z, Gao C. Fabrication of poly(lactideco-glycolide) scaffold filled with fibrin gel, mesenchymal stem cells, and poly(ethylene oxide)-b-poly(L-lysine)/TGF-beta1 plasmid DNA complexes for cartilage restoration in vivo. $J$ Biomed Mater Res A. 2013;101(11):3097-3108.

145. Li B, Yang J, Ma L, Li F, Tu Z, Gao C. Influence of the molecular weight of poly(lactide-co-glycolide) on the in vivo cartilage repair by a construct of poly(lactide-co-glycolide)/fibrin gel/mesenchymal stem cells/transforming growth factor-beta1. Tissue Eng Part A. September 17, 2013. [Epub ahead of print.]

146. Miller RE, Grodzinsky AJ, Vanderploeg EJ, et al. Effect of selfassembling peptide, chondrogenic factors, and bone marrow-derived stromal cells on osteochondral repair. Osteoarthritis Cartilage. 2010;18(12):1608-1619.

147. Mrugala D, Bony C, Neves N, et al. Phenotypic and functional characterisation of ovine mesenchymal stem cells: application to a cartilage defect model. Ann Rheum Dis. 2008;67(3):288-295.

148. Pagnotto MR, Wang Z, Karpie JC, Ferretti M, Xiao X, Chu CR. Adeno-associated viral gene transfer of transforming growth factorbeta1 to human mesenchymal stem cells improves cartilage repair. Gene Ther. 2007;14(10):804-813.

149. Park JS, Woo DG, Yang HN, et al. Chondrogenesis of human mesenchymal stem cells encapsulated in a hydrogel construct: neocartilage formation in animal models as both mice and rabbits. J Biomed Mater Res A. 2010;92(3):988-996.

150. Qi BW, Yu AX, Zhu SB, Zhou M, Wu G. Chitosan/poly(vinyl alcohol) hydrogel combined with Ad-hTGF-betal transfected mesenchymal stem cells to repair rabbit articular cartilage defects. Exp Biol Med (Maywood). 2013;238(1):23-30.
151. Wang W, Li B, Li Y, Jiang Y, Ouyang H, Gao C. In vivo restoration of full-thickness cartilage defects by poly(lactide-co-glycolide) sponges filled with fibrin gel, bone marrow mesenchymal stem cells and DNA complexes. Biomaterials. 2010;31(23):5953-5965.

152. Wu G, Cui Y, Ma L, Pan X, Wang X, Zhang B. Repairing cartilage defects with bone marrow mesenchymal stem cells induced by CDMP and TGF-beta. Cell Tissue Bank. March 5, 2013. [Epub ahead of print.]

153. Kubo S, Cooper GM, Matsumoto T, et al. Blocking vascular endothelial growth factor with soluble Flt-1 improves the chondrogenic potential of mouse skeletal muscle-derived stem cells. Arthritis Rheum. 2009;60(1):155-165.

154. Kuroda R, Usas A, Kubo S, et al. Cartilage repair using bone morphogenetic protein 4 and muscle-derived stem cells. Arthritis Rheum. 2006;54(2):433-442.

155. Matsumoto T, Cooper GM, Gharaibeh B, et al. Blocking VEGF as a potential approach to improve cartilage healing after osteoarthritis. J Musculoskelet Neuronal Interact. 2008;8(4):316-317.

156. Matsumoto T, Cooper GM, Gharaibeh B, et al. Cartilage repair in a rat model of osteoarthritis through intraarticular transplantation of muscle-derived stem cells expressing bone morphogenetic protein 4 and soluble Flt-1. Arthritis Rheum. 2009;60(5):1390-1405.

157. Mifune Y, Matsumoto T, Takayama K, et al. The effect of plateletrich plasma on the regenerative therapy of muscle derived stem cells for articular cartilage repair. Osteoarthritis Cartilage. 2013;21(1): $175-185$.

158. Park J, Gelse K, Frank S, von der Mark K, Aigner T, Schneider H. Transgene-activated mesenchymal cells for articular cartilage repair: a comparison of primary bone marrow-, perichondrium/periosteumand fat-derived cells. $J$ Gene Med. 2006;8(1):112-125.

159. Reyes R, Pec MK, Sanchez E, del Rosario C, Delgado A, Evora C. Comparative, osteochondral defect repair: stem cells versus chondrocytes versus bone morphogenetic protein-2, solely or in combination. Eur Cell Mater. 2013;25:351-365.

160. Katayama R, Wakitani S, Tsumaki N, et al. Repair of articular cartilage defects in rabbits using CDMP1 gene-transfected autologous mesenchymal cells derived from bone marrow. Rheumatology (Oxford). 2004;43(8):980-985.

161. Zhu S, Zhang B, Man C, Ma Y, Liu X, Hu J. Combined effects of connective tissue growth factor-modified bone marrow-derived mesenchymal stem cells and $\mathrm{NaOH}$-treated PLGA scaffolds on repair of articular cartilage defect in rabbits. Cell Transplant. July 11, 2013. [Epub ahead of print.]

162. Cao L, Yang F, Liu G, et al. The promotion of cartilage defect repair using adenovirus mediated Sox 9 gene transfer of rabbit bone marrow mesenchymal stem cells. Biomaterials. 2011;32(16):3910-3920.

163. Im GI, Kim HJ, Lee JH. Chondrogenesis of adipose stem cells in a porous PLGA scaffold impregnated with plasmid DNA containing SOX trio (SOX-5,-6 and -9) genes. Biomaterials. 2011;32(19): 4385-4392.

164. Lee JM, Im GI. SOX trio-co-transduced adipose stem cells in fibrin gel to enhance cartilage repair and delay the progression of osteoarthritis in the rat. Biomaterials. 2012;33(7):2016-2024.

165. Liu TM, Guo XM, Tan HS, Hui JH, Lim B, Lee EH. Zinc-finger protein 145 , acting as an upstream regulator of SOX9, improves the differentiation potential of human mesenchymal stem cells for cartilage regeneration and repair. Arthritis Rheum. 2011;63(9): $2711-2720$

166. Hu B, Ren JL, Zhang JR, Ma Q, Liu YP, Mao TQ. Enhanced treatment of articular cartilage defect of the knee by intra-articular injection of Bcl-xL-engineered mesenchymal stem cells in rabbit model. J Tissue Eng Regen Med. 2010;4(2):105-114.

167. Fan H, Hu Y, Qin L, Li X, Wu H, Lv R. Porous gelatin-chondroitinhyaluronate tri-copolymer scaffold containing microspheres loaded with TGF-beta1 induces differentiation of mesenchymal stem cells in vivo for enhancing cartilage repair. J Biomed Mater Res A. 2006;77(4): 785-794. 
168. Little CB, Zaki S. What constitutes an "animal model of osteoarthritis" - the need for consensus? Osteoarthritis Cartilage. 2012;20(4):261-267.

169. Poole R, Blake S, Buschmann M, et al. Recommendations for the use of preclinical models in the study and treatment of osteoarthritis. Osteoarthritis Cartilage. 2010;18 Suppl 3:S10-S16.

170. Evans CH, Ghivizzani SC, Robbins PD. Arthritis gene therapy's first death. Arthritis Res Ther. 2008;10(3):110-118.

171. Brand C. Intra-articular and soft tissue injections. Aust Fam Physician. 1990;19(5):671-675, 678, 680-672.

172. Cardone DA, Tallia AF. Diagnostic and therapeutic injection of the hip and knee. Am Fam Physician. 2003;67(10):2147-2152.

173. Courtney P, Doherty M. Joint aspiration and injection. Best Pract Res Clin Rheumatol. 2005;19(3):345-369.

174. Courtney P, Doherty M. Joint aspiration and injection and synovial fluid analysis. Best Pract Res Clin Rheumatol. 2009;23(2):161-192.

175. Courtney P, Doherty M. Joint aspiration and injection and synovial fluid analysis. Best Pract Res Clin Rheumatol. 2013;27(2):137-169.

176. Lockman LE. Practice tips. Knee joint injections and aspirations: the triangle technique. Can Fam Physician. 2006;52(11):1403-1404.

177. Pfenninger JL. Injections of joints and soft tissue: Part II. Guidelines for specific joints. Am Fam Physician. 1991;44(5):1690-1701.

178. Wittich CM, Ficalora RD, Mason TG, Beckman TJ. Musculoskeletal injection. Mayo Clin Proc. 2009;84(9):831-836.

179. Bathis H, Perlick L, Blum C, Luring C, Perlick C, Grifka J. Midvastus approach in total knee arthroplasty: a randomized, double-blinded study on early rehabilitation. Knee Surg Sports Traumatol Arthrosc. 2005;13(7):545-550.

180. Bridgman S, Walley G, MacKenzie G, Clement D, Griffiths D, Maffulli N. Sub-vastus approach versus the medial parapatellar approach in primary total knee: a randomised controlled trial [ISRCTN44544446]. Trials. 2006;7:23-29.

181. Engh GA, Parks NL. Surgical technique of the midvastus arthrotomy. Clin Orthop Relat Res. 1998(351):270-274.

182. Floren M, Reichel H, Davis J, Laskin RS. The mini-incision midvastus approach for total knee arthroplasty. Oper Orthop Traumatol. 2008;20(6):534-543.

183. Frosch KH, Voss M, Walde T, et al. A minimally invasive dorsal approach to the medial femoral condyle as a donor site for osteochondral transfer procedures. Oper Orthop Traumatol. 2010;22(2):212-220.

184. Maestro A, Suarez MA, Rodriguez L, Guerra C, Murcia A. The midvastus surgical approach in total knee arthroplasty. Int Orthop. 2000;24(2):104-107.

185. Tenholder M, Clarke HD, Scuderi GR. Minimal-incision total knee arthroplasty: the early clinical experience. Clin Orthop Relat Res. 2005;440:67-76.

186. Tria AJ Jr. Minimally invasive total knee arthroplasty: past, present, and future. Am J Orthop (Belle Mead NJ). 2007;36(Suppl 9):6-7.

187. Tarlov AR, Ware JE Jr, Greenfield S, Nelson EC, Perrin E, Zubkoff M. The Medical Outcomes Study. An application of methods for monitoring the results of medical care. JAMA. 1989;262(7): 925-930.

188. Aitken RC. Measurement of feelings using visual analogue scales. Proc R Soc Med. 1969;62(10):989-993.

189. Hefti F, Muller W, Jakob RP, Staubli HU. Evaluation of knee ligament injuries with the IKDC form. Knee Surg Sports Traumatol Arthrosc. 1993;1(3-4):226-234.

190. Irrgang JJ, Anderson AF, Boland AL, et al. Development and validation of the international knee documentation committee subjective knee form. Am J Sports Med. 2001;29(5):600-613.

191. Lysholm J, Gillquist J. Evaluation of knee ligament surgery results with special emphasis on use of a scoring scale. Am J Sports Med. 1982;10(3):150-154.

192. Roos EM, Roos HP, Lohmander LS, Ekdahl C, Beynnon BD. Knee Injury and Osteoarthritis Outcome Score (KOOS) - development of a self-administered outcome measure. J Orthop Sports Phys Ther. 1998;28(2):88-96.
193. Ranawat CS, Shine JJ. Duo-condylar total knee arthroplasty. Clin Orthop Relat Res. 1973(94):185-195.

194. Bellamy N, Buchanan WW, Goldsmith CH, Campbell J, Stitt LW. Validation study of WOMAC: a health status instrument for measuring clinically important patient relevant outcomes to antirheumatic drug therapy in patients with osteoarthritis of the hip or knee.J Rheumatol. 1988;15(12):1833-1840.

195. Lee KB, Wang VT, Chan YH, Hui JH. A novel, minimally-invasive technique of cartilage repair in the human knee using arthroscopic microfracture and injections of mesenchymal stem cells and hyaluronic acid - a prospective comparative study on safety and short-term efficacy. Ann Acad Med Singapore. 2012;41(11):511-517.

196. Saw KY, Anz A, Merican S, et al. Articular cartilage regeneration with autologous peripheral blood progenitor cells and hyaluronic acid after arthroscopic subchondral drilling: a report of 5 cases with histology. Arthroscopy. 2011;27(4):493-506.

197. Saw KY, Anz A, Siew-Yoke Jee C, et al. Articular cartilage regeneration with autologous peripheral blood stem cells versus hyaluronic acid: a randomized controlled trial. Arthroscopy. 2013;29(4): 684-694.

198. Skowronski J, Skowronski R, Rutka M. Cartilage lesions of the knee treated with blood mesenchymal stem cells - results. Ortop Traumatol Rehabil. 2012;14(6):569-577.

199. Adachi N, Ochi M, Deie M, Ito Y. Transplant of mesenchymal stem cells and hydroxyapatite ceramics to treat severe osteochondral damage after septic arthritis of the knee. J Rheumatol. 2005;32(8): $1615-1618$.

200. Buda R, Vannini F, Cavallo M, Grigolo B, Cenacchi A, Giannini S. Osteochondral lesions of the knee: a new one-step repair technique with bone-marrow-derived cells. J Bone Joint Surg Am. 2010;92 Suppl 2: $2-11$.

201. Gigante A, Calcagno S, Cecconi S, Ramazzotti D, Manzotti S, Enea D. Use of collagen scaffold and autologous bone marrow concentrate as a one-step cartilage repair in the knee: histological results of secondlook biopsies at 1 year follow-up. Int J Immunopathol Pharmacol. 2011;24(1 Suppl 2):69-72.

202. Haleem AM, Singergy AA, Sabry D, et al. The clinical use of human culture-expanded autologous bone marrow mesenchymal stem cells transplanted on platelet-rich fibrin glue in the treatment of articular cartilage defects: a pilot study and preliminary results. Cartilage. 2010;1(4):253-261.

203. Kasemkijwattana C, Hongeng S, Kesprayura S, Rungsinaporn V, Chaipinyo K, Chansiri K. Autologous bone marrow mesenchymal stem cells implantation for cartilage defects: two cases report. J Med Assoc Thai. 2011;94(3):395-400.

204. Kuroda R, Ishida K, Matsumoto T, et al. Treatment of a full-thickness articular cartilage defect in the femoral condyle of an athlete with autologous bone-marrow stromal cells. Osteoarthritis Cartilage. 2007;15(2):226-231.

205. Nejadnik H, Hui JH, Feng Choong EP, Tai BC, Lee EH. Autologous bone marrow-derived mesenchymal stem cells versus autologous chondrocyte implantation: an observational cohort study. Am J Sports Med. 2010;38(6):1110-1116.

206. Skowronski J, Rutka M. Osteochondral lesions of the knee reconstructed with mesenchymal stem cells - results. Ortop Traumatol Rehabil. 2013;15(3):195-204.

207. Skowronski J, Skowronski R, Rutka M. Large cartilage lesions of the knee treated with bone marrow concentrate and collagen membrane - results. Ortop Traumatol Rehabil. 2013;15(1): 69-76.

208. Slynarski K, Deszczynski J, Karpinski J. Fresh bone marrow and periosteum transplantation for cartilage defects of the knee. Transplant Proc. 2006;38(1):318-319.

209. Wakitani S, Mitsuoka T, Nakamura N, Toritsuka Y, Nakamura Y, Horibe S. Autologous bone marrow stromal cell transplantation for repair of full-thickness articular cartilage defects in human patellae: two case reports. Cell Transplant. 2004;13(5):595-600. 
210. Wakitani S, Nawata M, Tensho K, Okabe T, Machida H, Ohgushi H. Repair of articular cartilage defects in the patello-femoral joint with autologous bone marrow mesenchymal cell transplantation: three case reports involving nine defects in five knees. J Tissue Eng Regen Med. 2007;1(1):74-79.

211. Oslo University Hospital. Mesenchymal Stem Cells in a Clinical Trial to Heal Articular Cartilage Defects. Available from: http://clinicaltrials. gov/show/NCT00885729. NLM identifier: NCT00885729. Accessed December 19, 2014.

212. Cairo University. The Use of Autologous Bone Marrow Mesenchymal Stem Cells in the Treatment of Articular Cartilage Defects. Available from: http://clinicaltrials.gov/show/NCT00891501. NLM identifier: NCT00891501. Accessed December 19, 2013.

213. Royan Institute. Autologous Transplantation of Mesenchymal Stem Cells (MSCs) and Scaffold in Full-thickness Articular Cartilage. Available from: http://clinicaltrials.gov/show/NCT00850187. NLM identifier: NCT00850187. Accessed December 19, 2013.

214. Michel Assor, MD. Transplantation of Bone Marrow Stem Cells Stimulated by Proteins Scaffold to Heal Defects Articular Cartilage of the Knee. Available from: http://clinicaltrials.gov/show/ NCT01159899. NLM identifier: NCT01159899. Accessed December 19, 2013.

215. Fundacion para la InvestigacionBiomedicadel Hospital Universitario la Paz. Autologous Mesenchymal Stem Cells vs. Chondrocytes for the Repair of Chondral Knee Defects (ASCROD). Available from: http://clinicaltrials.gov/show/NCT01399749. NLM identifier: NCT01399749. Accessed December 19, 2013.

216. Medipost Co Ltd. Study to Compare the Efficacy and Safety of Cartistem $^{\circledR}$ and Microfracture in Patients With Knee Articular Cartilage Injury or Defect. Available from: http://clinicaltrials.gov/show/ NCT01041001. NLM identifier: NCT01041001. Accessed December 19, 2013.

217. Medipost Co Ltd. Follow-Up Study of CARTISTEM ${ }^{\circledR}$ Versus Microfracture for the Treatment of Knee Articular Cartilage Injury or Defect. Available from: http://clinicaltrials.gov/show/NCT01626677. NLM identifier: NCT01626677. Accessed December 19, 2013.

218. Medipost Co Ltd. Evaluation of Safety and Exploratory Efficacy of CARTISTEM $^{\circledR}$, a Cell Therapy Product for Articular Cartilage Defects. Available from: http://clinicaltrials.gov/show/NCT01733186. NLM identifier: NCT01733186. Accessed December 19, 2013.

219. Centeno CJ, Busse D, Kisiday J, Keohan C, Freeman M, Karli D. Increased knee cartilage volume in degenerative joint disease using percutaneously implanted, autologous mesenchymal stem cells. Pain Physician. 2008;11(3):343-353.

220. Davatchi F, Abdollahi BS, Mohyeddin M, Shahram F, Nikbin B. Mesenchymal stem cell therapy for knee osteoarthritis. Preliminary report of four patients. Int J Rheum Dis. 2011;14(2):211-215.

221. Emadedin M, Aghdami N, Taghiyar L, et al. Intra-articular injection of autologous mesenchymal stem cells in six patients with knee osteoarthritis. Arch Iran Med. 2012;15(7):422-428.

222. Orozco L, Munar A, Soler R, et al. Treatment of knee osteoarthritis with autologous mesenchymal stem cells: a pilot study. Transplantation. 2013;95(12):1535-1541.

223. Varma HS, Dadarya B, Vidyarthi A. The new avenues in the management of osteo-arthritis of knee - stem cells. J Indian Med Assoc. 2010;108(9):583-585.

224. Koh YG, Choi YJ. Infrapatellar fat pad-derived mesenchymal stem cell therapy for knee osteoarthritis. Knee. 2012;19(6):902-907.

225. Koh YG, Jo SB, Kwon OR, et al. Mesenchymal stem cell injections improve symptoms of knee osteoarthritis. Arthroscopy. 2013;29(4): 748-755.

226. Pak J. Regeneration of human bones in hip osteonecrosis and human cartilage in knee osteoarthritis with autologous adipose-tissue-derived stem cells: a case series. J Med Case Rep. 2011;5:296-303.
227. Wakitani S, Imoto K, Yamamoto T, Saito M, Murata N, Yoneda M. Human autologous culture expanded bone marrow mesenchymal cell transplantation for repair of cartilage defects in osteoarthritic knees. Osteoarthritis Cartilage. 2002;10(3):199-206.

228. International Stemcell Services Limited. Safety and Efficacy of Autologous Bone Marrow Stem Cells for Treating Osteoarthritis. Available from: http://clinicaltrials.gov/show/NCT01152125. NLM identifier: NCT01152125. Accessed December 19, 2013.

229. Hospital Universitario Dr. Jose E. Gonzalez. Autologous Stem Cells in Osteoarthritis. Available from: http://clinicaltrials.gov/show/ NCT01485198. NLM identifier: NCT01485198. Accessed December 19, 2013.

230. Paulo Brofman. Autologous Bone Marrow Mesenchymal Stem Cells Transplantation for Articular Cartilage Defects Repair. Available from: http://www.clinicaltrials.gov/ct2/show/NCT01895413. NLM identifier: NCT01895413. Accessed December 19, 2013.

231. Mayo Clinic. Use of Autologous Bone Marrow Aspirate Concentrate in Painful Knee Osteoarthritis (BMAC). Available from: http://clinicaltrials.gov/ct2/show/NCT01931007. NLM identifier: NCT01931007. Accessed December 19, 2013.

232. Nantes University Hospital. Regenerative Medicine of Articular Cartilage: Characterization and Comparison of Chondrogenic Potential and Immunomodulatory Adult Mesenchymal Stem Cells (ARTHROSTEM). Available from: http://clinicaltrials.gov/ct2/show/ NCT01879046. NLM identifier: NCT01879046. Accessed December 19, 2013

233. Stempeutics Research Pvt Ltd. Allogeneic Mesenchymal Stem Cells for Osteoarthritis. Available from: http://clinicaltrials.gov/show/ NCT01448434. NLM identifier: NCT01448434. Accessed December 19, 2013.

234. Stempeutics Research Pvt Ltd. Allogeneic Mesenchymal Stem Cells in Osteoarthritis. Available from: http://clinicaltrials.gov/show/ NCT01453738. NLM identifier: NCT01453738. Accessed December 19, 2013.

235. National University of Malaysia. Intra-Articular Autologous Bone Marrow Mesenchymal Stem Cells Transplantation to Treat Mild to Moderate Osteoarthritis. Available from: http://clinicaltrials.gov/show/ NCT01459640. NLM identifier: NCT01459640. Accessed December 19, 2013.

236. RNL Bio Company Ltd. Autologous Adipose Tissue Derived Mesenchymal Stem Cells Transplantation in Patient With Degenerative Arthritis. Available from: http://clinicaltrials.gov/show/NCT01300598. NLM identifier: NCT01300598. Accessed December 19, 2013.

237. University Hospital, Montpellier. ADIPOA - Clinical Study. Available from: http://clinicaltrials.gov/show/NCT01585857. NLM identifier: NCT01585857. Accessed December 19, 2013.

238. Ageless Regenerative Institute. Autologous Adipose-Derived Stromal Cells Delivered Intra-articularly in Patients With Osteoarthritis. Available from: http://clinicaltrials.gov/show/NCT01739504. NLM identifier: NCT01739504. Accessed December 19, 2013.

239. Cellular Biomedicine Group Ltd. Autologous Adipose Tissue Derived Mesenchymal Progenitor Cells Therapy for Patients With Knee Osteoarthritis. Available from: http://clinicaltrials.gov/show/ NCT01809769. NLM identifier: NCT01809769. Accessed December 19, 2013.

240. Translational Biosciences. Safety and Feasibility Study of Autologous Stromal Vascular Fraction (SVF) Cells for Treatment of Osteoarthritis. Available from: http://clinicaltrials.gov/show/NCT01885832. NLM identifier: NCT01885832. Accessed December 19, 2013.

241. Institute of Regenerative and Cellular Medicine. Safety and Clinical Effectiveness of A3 SVF in Osteoarthritis. Available from: http:// www.clinicaltrials.gov/show/NCT01947348. NLM identifier: NCT01947348. Accessed December 19, 2013. 


\section{Publish your work in this journal}

Stem Cells and Cloning: Advances and Applications is an international, peer-reviewed, open access journal. Areas of interest in stem cell research include: Embryonic stem cells; Adult stem cells; Blastocysts; Cordblood stem cells; Stem cell transformation and culture; Therapeutic cloning; Umbilical cord blood and bone marrow cells; Laboratory, animal and human therapeutic studies; Philosophical and ethical issues related to stem cell research. This journal is indexed on CAS. The manuscript management system is completely online and includes a quick and fair peer-review system. Visit http://www.dovepress.com/ testimonials.php to read real quotes from published authors.

\footnotetext{
Submit your manuscript here: http://www.dovepress.com/stem-cells-and-cloning-advances-and-applications-journal
} 